\title{
ANALISIS KEBIJAKAN MANAJEMEN KEUANGAN MI MUHAMMADIYAH CANDIREJO
}

\author{
Ilham \\ ilhamtarbiyah@gmail.com
}

\begin{abstract}
Abstrak
Tata kelola keuangan di satuan pendidikan sangat penting sebagai pembangunan sarana prasarana yang menunjang keberhasilan pendidikan. Fokus penelitian ini adalah bagaimanakah pengelolaan anggaran terhadap pengembangan sarana prasarana MI di Muhammadiyah Candirejo. Metode penelitian bersifat field research di MI Muhammadiyah Candirejo. Hasil penelitian menunjukan bahwa anggaran dana untuk sarana dan prasarana masih belum mencukupi untuk Madrasah Ibtidaiyah Muhammadiyah Candirejo. Anggaran yang sampai kepada MI tidaklah $100 \%$ tetapi dalam pembuatan laporan haruslah $100 \%$.Ranting Muhammadiyah juga menyumbang pendanaan untuk menggaji guru ditambah dengan diambilkan dana BOS. Adanya penarikan sebesar Rp.10.000 ditiap bulan untuk memenuhi pendanaan kegiatan ekstrakurikuler itupun tidak mencukupi sehingga untuk menggaji para pelatih ditambah dana BOS.
\end{abstract}

Kata Kunci: Anggara, Kebijakan, Manajemen

\section{PENDAHULUAN}

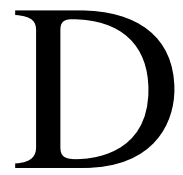

alam penyelenggaraan pendidikan, keuangan dan pembiayaan merupakan potensi yang sangat menentukan dan merupakan bagian tak terpisahkan dari kajian manajemen pendidikan.

Komponen keuangan dan pembiayaan pada suatu sekolah merupakan komponen produksi yang menentukan terlaksananya kegiatan-kegiatan proses belajar-mengajar disekolah bersama komponen-komponen lain. Dengan kata lain, setiap kegiatan yang dilakukan sekolah memerlukan biaya, baik itu disadari maupun tidak disadari. Komponen keuangan dan pembiayaan ini perlu dikelola sebaik-baiknya, agar dana-dana yang ada dapat dimanfaatkan secara optimal untuk menunjang tercapainya tujuan pendidikan.

Sumber keuangan dan pembiayaan pada suatu sekolah secara garis besar dapat dikelompokan atas tiga sumber, yaitu: (1) pemerintah, baik pemerintah pusat maupun pemerintah daerah, yang bersifat umum atau khusus dan di peruntukan bagi kepentingan pendidikan; (2) orangtua peserta didik; (3) masyarakat, baik 
mengikat maupun tidak mengikat. Berkaitan dengan penerimaan keuangan dari orangtua dan masyarakat, karena keterbatasan kemampuan pemerintah dalam pemenuhan kebutuhan dana pendidikan, tanggung jawab atas pemenuhan kebutuhan dana pendidikan merupakan tanggung jawab bersama antara pemerintahan, masyarakat, dan orangtua (Mulyasa, 2011: 85).

UUSPN No. 20 Tahun 2003 menyebutkan bahwa alokasi dana pendidikan selain gaji pendidik dan biaya pendidik kedinasan dialokasikan minimal 20\% dari anggaran pendapatan dan belanja negara (APBN) pada sektor pendidikan dan minimal 20\% dari anggaran pendapatan dan belanja daerah (APBD).Untuk lebih jelas mengenai pembiayaan pendidikan ini dapat dibaca pada peraturan pemerintahan Nomor 48 Tahun 2008 tentang pendanaan pendidikan. Adapun pengertian lain dari pembiayaan pendidikan, sebagaimana yang diutarakan Nanang Fatah, merupakan jumlah uang yang dihasilkan dan dibelanjakan untuk berbagai keperluan penyelenggaraan pendidikan yang mencakup gaji guru, peningkatan profesional guru, pengadaan sarana ruang belajar, perbaikan ruang, pengadaan peralatan/mobile, pengadaan alat-alat dan buku pelajaran, alat tulis kantor (ATK), kegiatan ekstrakulikuler, kegiatan pengelolaan pendidikan, dan supervisi pendidikan (Imam Machali, 2016: 196).

Pada tanggal 13 April 2018, peneliti melakukan wawancara langsung dengan Kepala Sekolah MI Muhammadiyah Candirejo yang bernama Erna Meisaroh, S.Ag., M.Pd.I yang menyatakan bahwa sumber dana yang didapat berasal dari dana BOS yang dikeluarkan 6 bulan sekali oleh pemerintah serta bantuan subsidi berupa tunjangan dari Pimpinan Daerah Muhammadiyah/PDM sebagai anggaran tambahan yang menunjang gaji pra guru honor yang sedang bertugas. Setiap tahun juga peserta didik yang mempunyai kartu pintar akan mendapatkan BSM melalui nomor rekening atas nama siswa tersebut. BSM yang diberikanpun berbeda beda nominalnya. Selain itu,pihak komite juga menarik uang sebesar Rp 10.000,-/siswa untuk biaya ekstrakulikuler yang diikuti oleh peserta didik tersebut.Sebagaimana dikemukakan oleh kepala sekolah MI Muhammadiyah Candirejo diatas, maka hal itu juga dapat kita kaitkan dengan keberhasilan program pendidikan pada madrasah tersebut. Dalam belajar mengajar sangat dipengaruhi beberapa 
faktor, seperti siswa, kurikulum, pendidik dan tenaga kependidikan, dana, sarana dan prasarana dan faktor lingkungan. Salah satu faktor yang mendukung keberhasilan program pendidikan dalam proses pembelajaran adalah sarana dan prasarana pendidikan. Pengeluaran dana BOS tidak sertamerta digunakan untuk gaji para tenaga pengajar melainkan untuk melengkapi sarana prasarana yang ada disekolah tersebut.

\section{Konsep Kebijakan Pendidikan}

MerujukpandanganHasbulah (2015)bahwaistilah "Kebijakan" merupakan terjemahan dari kata "policy" dalam bahasa Inggris, yang berarti mengurus masalah atau kepentingan umum, atau berarti juga administrasi pemerintah. Menurut Imron dalam Syaiful Sagala (2008:97) kebijakan merupakan terjemahan dari kata "wisdom" yaitu suatu ketentuan dari pimpinan yang berbeda dengan aturan yang ada, yang dikenakan pada sesorang atau kelompok. Sedangkan menurut Kamus Besar Bahasa Indonesia (1988) mengemukakan bahwa kebijakan adalah kepandaian; kemahiran; kebijaksanaan; rangkaian konsep dan asas yang menjadi garis dasar dan dasar rencana dalam pelaksanaan pekerjaan; kepemimpinan dan cara bertindak oleh pemerintah, organisasi dan sebagainya sebagai pernyataan cita-cita, tujuan, prinsip, atau maksud; sebagai pedoman untuk manajemen dalam mencapai sasaran.

Menurut Ratana Dewi (2016), bahwasannya kebijakan (policy) secara "etimologi diturunkan dari bahasa Yunani, Yaitu polis yang artinya kota (city), kebijakan berkenaan dengan gagasan pengaturan organisasi dan merupakan pola formal yang sama-sama diterima pemerintah/lembaga sehingga dengan hal itu mereka berusaha mengejar tujuannya."Abidin menjelaskan kebijakan adalah "keputusan pemerintah yang bersifat umum dan berlaku untuk seluruh anggota masyarakat.Lebihlanjut, Richard SimeondalamFuadi Aziz, (2014) mengatakan "what goverments actually do and why", Kebijakan adalah apa yang dilakukan oleh pemerintah dan mengapa melakukannya. Sedangkan E Hugh Heclo sebagaimana dikutip oleh Oberlin Silalahi 
menyatakan bahwa kebijakan adalah cara bertindak yang Richard Simeon "what goverments actually do and why", Kebijakan adalah apa yang dilakukan oleh pemerintah dan mengapa melakukannya. (Fuadi Aziz, 2014).

Secara konseptual, ada beragam pengertian yang diberikan para ahli tentang kebijakan. Namun secara umum "kebijakan" dapat dikatakan suatu rumusan keputusan pemerintahan yang menjadi pedoman tingkah laku guna mengatasi masalah atau persoalan yang didalamnya terdapat tujuan rencana dan program yang akan dilaksanakann.Istilah "kebijakan pendidikan" merupakan terjemahan dari "educational policy", yang tergabung dari kata education dan policy. Kebijakan adalah seperangkat aturan, sedangkan pendidikan menunjuk kepada bidangnya. Jadi kebijakan pendidikan hampir sama artinya dengan kebijakan pemerintah dalam bidang pendidikan.Kebijakan pendidikan disini dimaksudkan adalah seperangkat aturan sebagai bentuk keberpihakan dari pemerintah dalam upaya membangun satu sistem pendidikan sesuai dengan tujuan dan cita-cita yang diinginkan bersama, keberpihakan tersebut menyangkut dalam konteks politik, anggaran, pemberdayaan, tata aturan, dan sebagainya. Kebijakan pendidikan merupakan keseluruhan proses dan hasil perumusan langkah-langkah strategi pendidikan yang dijabarkan dari visi dan misi pendidikan, dalam rangka mewujudkan tercapainya tujuan pendidikan dalam suatu masyarakat untuk suatu kurun waktu tertentu. (Hasbullah, 2015: 38-40).

\section{Profil Madrasah Ibtidaiyah Muhammadiyah Candirejo}

Madrasah Ibtidaiyah Muhammadiyah Candirejo berdiri sejak tahun 1958 dengan nama MI Muhammadiyah di bawah pengelolaan Pimpinan Ranting Muhammadiyah Ranting Candirejo yang dipimpin oleh almarhum Drs. H. Markum. Madrasah ini berdiri di atas tanah wakaf seluas $1.754 \mathrm{~m} 2$.MI Muhammadiyah Candirejo telah mengalami beberapa kemajuan dalam beberapa aspek, tetapi masih banyak 
persoalan dan tantangan yang perlu segera di tindak lanjuti. Berikut visi, misi dan tujuan berdirinya madrasah:

\section{Visi MI Muhammadiyah Candirejo}

MI Muhammadiyah Candirejo sebagai lembaga pendidikan dasar bercirikhas Islam perlu mempertimbangkan harapan siswa, orangtua siswa, lembaga pengguna lulusan madrasah dan masyarakat dalam merumuskan visinya. MIM Candirejo juga diharapkan merespon perkembangan dan tantangan masa depan dalam ilmu pengetahuan dan teknologi, era informasi dan globalisasi yang sangat cepat. Visi tersebut adalah "Terwujudnya Potensi Anak Didik Menjadi Generasi Yang Beriman, Bertaqwa, Berakhlak Mulia, Cerdas, Trampil Dan Berprestasi"

a. Misi MI Muhammadiyah Candirejo

1) Menumbuhkan penghayatan dan kedisiplinan terhadap ajaran agama sehingga tercipta insan yang beriman, bertaqwa dan berakhlak mulia

2)Melaksanakan bimbingan pembelajaran secara efektif sehingga anak didik dapat mengembangkan potensi sertabakat yang dimiliki secara optimal

3)Meningkatkan kegiatan belajar mengajar secara efektif yang berorientasi pada kemandirian anak didik

4)Menyelenggarakan dan mengikuti segala kegiatan yang menunjang peningkatan prestasi anak didik

5)Menerapkan manajemen sekolah yang menumbuhkan partisipasi masyarakat dalam upaya terselenggaranya pendidikan yang berkualitas

b. Tujuan MI Muhammadiyah Candirejo

1)Anak didik memiliki kesadaran melaksanakan kewajibannya sebagai hamba kepadaAllah SWT

2)Anak didik mengetahui potensi yang dimiliki serta dapat meningkatkan kematangan bakat masing-masing

3) Anak didik secara sadar melaksanakan tugas dan kewajibannya sebagai pelajar 
4) Anak didik memiliki keberanian dan percaya diri untuk menunjukkan prestasi yang dimiliki kepada masyarakat

5)Mencetak lulusan yang berkualitas menuju jenjang yang lebih tinggi

Data yang tersaji adalah profil singkat MI Muhammadiyah Candirejo, Ngawen, Klaten, Jawa Tengah yang terletak di Dusun Karasan, Desa Candirejo, Kecamatan Ngawen, Kabupaten Klaten, Jawa Tengah. Status Madrasah tersebut A sejaktahun 2011, sampaipadatahun 2016 dilakukan akreditasi atau penilaian. Data tersebut dapat dilihat adanya peningkatan di setiap tahun ajaran dilihat dari segi banyaknya siswa yang masuk pendaftaran baru maupun siswa mutasi dari sekolah lain, banyak orang tua yang lebih memilih ke MI dibandingkan di SD Negeri.

\section{Program Kerja Madrasah Ibtidaiyah Muhammadiyah Candirejo}

Bidang-bidang garapan pengelolaan sekolah/madrasah adalah: kurikulum, pesertadidik, pendidik dan tenaga pendidik, keuangan, sarana dan prasarana, hubungan sekolah dengan masyarakat. Salah satu yang menjadi bahasan pada tema manajemen pengelolaan madrasah adalah bagaimana program kerja madrasah mulai dari Rencana Kerja Madrasah (RKM) untuk 5 tahunkedepan, dan Rencana Kerja Tahunan (RKT) yaitu program menengah yang direncanakan tiap setahun sekali. Berikut hasil observasi dan wawancara dengan Ibu Erna Maesaroh, S. Ag. M. Pd. I selaku Kepala MIM Candirejo:

Berdasarkan pengelompokan dan analisa katagori yang ada didalam materi RKM, secara garis besar RKM MI Muhammadiyah Candirejo tahun 2015-2018 dapat disimpulkan sebagai berikut :

a. Secara umum RKM MI MuhammadiyahCandirejo dapat dikelompokkan dalam 2 program umum yaitu :

1) Penyelenggaraan proses pendidikan wajardikdas 6 tahun.

2) Program manajemen pelayanan pendidikan.

b. Penyelenggaraan kegiatan yang bersifat rutinitas seperti peralatan dan sumber belajar baik untuk kegiatan teori maupun praktek dan 
kebutuhan biaya operasional perkantoran sehari-hari menjadi kebutuhan rutin tiap tahun.

c. Pengadaan sarana prasarana yang merupakan belanja modal dirumuskan dalam skala prioritas sebagai berikut:

1) Tahun 2015 diprioritaskan pada pengadaan $1 \mathrm{RKB}$, dan mebelair ruang kelas 1 unit.

2) Tahun 2015 diprioritaskan pada renovasi 1 buah kamar mandi/WC

3) Tahun 2016 diprioritaskan pada penambahan buku pegangan siswa baik mapel umum maupun PAI termasuk buku-buku referensi dan buku-buku cerita di perpustakaan serta sarana yang mendukung proses pembelajaran maupun perabotan UKS

4) Tahun 2017 diprioritaskan pada penambahan computer bagisiswasebanyak 20 unit

5) Tahun 2018 diprioritaskan pada penamabahan RKBdan toilet dilantaidua, dan pengadaan LAB TI/Komputer

d. Pembinaan dan pelatihan tenaga pendidik dan tenaga kependidikan dalam rangka peningkatan mutu dilaksanakan secara berkala dalam setiap tahun anggaran.

e. Kebutuhan biaya kegiatan diusahakan melalui pengajuan RKAM, Proposal, dan Pemberdayaan komite dan peran serta masyarakat.

RKT (Rencana Kerja Tahunan) khususnya pengembangan sarana dan prasarana, pengembangan standar pengelolaan dan pembiayaan di MIM Candirejo sebagai berikut, tahun 2018:

a. Pengembangan sarana prasarana, penanggungjawab langsung adalah Pak Nunuk Haryanto, S. Pd, I

1) Pengadaan tempat cucitangan di depan /halaman kelas

2) Pembelian 1 unit LCD proyektor sebagai sarana pembelajaran

3) Pembuatan buku catatan kesehatan peserta didik

4) Pembelian tempat sampah diletakkan di beberapa tempat

5) Pembelianalatolah raga danseni

6) Pembeliansarana lab IPA

7) Pembelian meja kursi

8) Pembelian buku perpustakaan dan buku pegangan siswa 
9) Perbaikan tempat parkir guru dan siswa

10) Penambahan ruang kelas siswa untuk sementara (jangka panjang sedang pengajuan proposal untuk pembangunan kelas baru dengan syarat memiliki lahan)

11) Perbaikan dan pembelian printer

b. Pengembangan standar pengelolaan dan pembiayaan, penanggung jawaba dalah Pak Sri Winarno, S.Pd.I, danSiti Nuryani, S.Pd.I

1) Workshop penyusunan RKM yaitu tentang dimilikinya RKM dan RKT disetujui oleh dewan guru dan komite Madrasah demi terwujudnya visi-misi dan tujuan madrasah

2)Evaluasi diri Madrasah untuk meningkatkan hasil belajar siswa secara berkelanjutan

3) Membeli atau memesan softwhare Sistem Informasi Manajemen

4) Mengikutsertakan guru dalam Diklat

5) Penilaian pendidik dalam bentuk supervisi guru

6) Pembinaan dan pembelajaran di lapangan (PKL)

7) Pertemuan dengan orang tua siswa disesuaikan dengan kebutuhandan kondisi

8) Rapat bersama komite

9) Workshop dan sosialisasi sistem pengelolaan BOS. (Sumer data, 2018).

RKM adalah rencana kerja Madrasah yang disusun oleh madrasah dan komite madrasah. Kebutuhan madrasah dan aspirasi masyarakat menjadi dasar utama penyusunan RKM. RKM merupakan rencana yang komprehensif untuk mengoptimalkan pemanfaatan segala sumber daya yang ada dan yang mungkin diperoleh guna mencapai tujuan yang diinginkan di masa mendatang. Kebijakan yang mengatur adanya RKM antaralain, PP No. 19/2005 tentang Standar Nasional Pendidikan Pasal 53 (Setiap satuan pendidikan dikelola atas dasar rencana kerja tahunan yang merupakan penjabaran perinci dari rencanakerjajangkamenengahsatuanpendidikan yang meliputimasa 4 tahun), Permendiknas 19 tahun 2007 tentang Standar Pengelolaan Pendidikan. Madrasah/ sekolah membuat Rencana Kerja Jangka Menengah (RKJM) tahun, Rencana Kerja Tahunan (RKT) dinyatakan 
dalam Rencana Kegiatan dan Anggaran Madrasah (RKAS/M) dilaksanakan berdasarkan RKJM. RKJM/T disetujui rapat dewan pendidik setelah memperhatikan pertimbangandari Komite Madrasah dan disahkan berlakunya oleh Dinas Pendidikan Kab/Kota. (Muhaimin, 2009: 199)

\section{Pengelolaan Anggaran dan Implementasi di Madrasah Ibtidaiyah Candirejo}

Pengelolaan anggaran adalah implementasi dari RKM. Anggaran yang diperolehakan digunakan untuk memperbaiki sistem pendidikan di madrasah, di MIMuhammadiyah Candirejo sumber dana adalah dari BOS (Bantuan Oprasional Sekolah). Perkiraan sumber pendanaan dan penyesuaian rencana biaya program dan sumber pendanaan. Di dalam perencanaan ini memuat asumsi rencana biaya dan pendanaan seperti terjadinya inflasi (perkiraan kenaikan harga) sebesar $10 \%$ per tahun , perubahan fisik madrasah sebesar $1 \%$ per tahun, dan pertumbuhan siswa selama 4 tahun ke depan sekitar $1 \%$ per tahun. Menurut data dari wawancara dengan Ibu Erna tahun 2018 bahwasannya anggaran yang sampai kepada MI tidaklah $100 \%$ tetapi dalam pembuatan laporan haruslah $100 \%$. Ranting Muhammadiyah juga menyumbang pendanaan untuk menggaji guru ditambah dengan diambilkandana BOS. Adanya penarikan sebesar Rp10.000 ditiap bulan untuk memenuhi pendanaan kegiatan ekstrakurikuler itupun tidak mencukupi sehingga untuk menggaji para pelatih ditambah dana BOS.(Wawancara, 2018).

BOS adalah Bantuan Oprasional Sekolah yang bertujuan meringankan beban biaya operasi sekolah bagi peserta didik SD/SDLB/SMP/SMPLB yang diselanggarakan oleh masyarakat. BOS yang diterimaoleh SD/SDLB/SMP/SMPLB dihitung berdasarkan jumlah peserta didik pada sekolah yang bersangkutan. Jumlah satuan biaya BOS adalah Rp800.000,-/ peserta didik/tahun. Waktu penyaluran dana BOS dilakukan setiap 6 bulan atau setiap semester. (Hariswati, 2016: 75). Perubahan kualitas tata kelola (governance) sekolah terutama aspek transparansi akuntabilitas, dan partisipasi yang membuat pengelolaan dana BOS kurang maksimal, di sisi lain masih ada kelemahan atau "penyakit" dalam penggunaan dana BOS di tingkat sekolah belum juga 
hilang, yaitu pelanggaran alokasi penggunaan dana BOS untuk gaji guru. Pemerintah menoleransi penggunaan dana BOS untuk gaji guru honorer maksimum hanya 20\% saja, tetapi kenyataanya masih banyak sekolah yang menggunakan dana BOS lebih dari $20 \%$ untuk gaji guru.(Hariswati, 2016: 88).

Pemerintah sendiri sebenarnya memberikan hak otonomi penuh atas pengelolaan asalkan terdapat RKAM yang dilaporkan secara transparan, RKAM juga dibuat berdasarkan persetujuan komite. Dari data MIM Candirejo penggunaan anggaran untuk pendidik dan tenaga kependidikan lebih dari $20 \%$ yaitu sebanyak 39\% hampir dua kali lipat dari peraturan pemerintahan. MIM Candirejo melaporkan secara transparan atas penggunaan anggaran meskipun sebenaranya tidak benar-benar mengikuti kebijakan dari pemerintahan, tetapi membuat kebijakan sendiri demi mencukupi pendanaan pendidik dan tenaga kependidikan.

UUSPN Nomor 20 tahun 2003 menyatakan, "Setiap satuan pendidikan formal dan nonformal menyediakan sarana dan prasarana yang memenuhi keperluan pendidikan sesuai dengan pertumbuhan dan perkembangan potensi fisik, kecerdasan intelektual, sosial, emosional, dan kejiwaan peserta didik”. Melengkapi sarana dan prasarana termasuk salah satu kunci keberhasilan pendidikan. Jika sarana dan prasarana minim, maka semangat anak didik bisa melemah dan presentasi bisa menjauh (Azmani, 2009: 59). Sementara itu Mulyadi (2015:87) menyebutkan posisi trategis manajemen sarana dan prasarana pendidikan bertugas mengatur dan menjaga sarana dan prasarana pendidikan agar dapat memberikan kontribusi secara optimal dan berarti pada jalannya proses pendidikan. Kegiatan pengelolaan ini meliputi kegiatan perencanaan, pengadaan, pengawasan, penyimpanan inventarisasi, dan penghapusan serta penataan.

Manajemen sarana dan prasarana yang baik diharapkan dapat menciptakan sekolah yang bersih, rapi, indah sehingga menciptakan kondisi yang menyenangkan baik bagi guru maupun murid untuk berada disekolah. Disamping itu juga diharapkan tersedianya alat-alat atau fasilitas belajar yang memadai secara kuantitatif, kualitatif, dan relevan dengan kebutuhan serta dapat 
dimanfaat secara optimal untuk kepentingan proses pendidikan dan pembelajaran, naik oleh guru maupun peserta didik.

Sebagaimana mestinya pada jurnal yang ditulis oleh Abdul Manaf (2018) juga menyatakan pandangansenadabahwa manajemen sarana dan prasarana sangat berperan penting dalam pencapaian tujuan pendidikan baik bersifat kualitatif maupun kuantitatif. Perencanaan pengadaan, pemanfaatan serta pemeliharaan sarana dan prasarana merupakan bagian yang tak terpisahkan dengan manajemen pendidikan.Pemakaian sarana dan prasarana sekolah juga erat kaitannya dengan penataannya. Sarana dan prasarana sekolah yang lengkap belum menjamin efektivitas dan efisiensi pemakaiannya tanpa diiringi dengan penataan yang baik. Hal ini untuk mencegah penghamburan tenaga dan waktu pemakainya. Kriteria tata ruang sarana dan prasarana sekolah mengacu pada Permendiknas No. 24 tahun 2007 tentang Standar Sarana dan Prasarana.Abdul Manaf (2018).

\section{SIMPULAN}

Dari hasil research yang dilakukan oleh peneliti menemukan bahwa anggaran dana untuk sarana dan prasarana masih belum mencukupi untuk Madrasah Ibtidaiyah Muhammadiyah Candirejo. Bukti kuat yang menyatakan itu didapat langsung dari wawancara yang dilakukan oleh para peneliti dan data yang berubah profil dari madrasah ibtidaiyah muhammadiyah candirejo. Dugaan itupun diperkuat lagi dengan adanya penelitian sebelumnya mengenai anggaran dana untuk pendidikan yang diteliti oleh Riant Nugroho (2008: 124) studi kasus yang ia teliti menyatakan bahwa pembangunan pendidikan dikabupaten Jembrana 2000-2006 mendapatkan seorang informan yang mempunyai jabatan tinggi di jembrana memperkirakan bahwa paling tinggi anggaran yang murni pendidikan adalah $15 \%$, sehingga temuan penelitian untuk tahun 2006 menunjukan bahwa anggaran yang murni pendidikan 8\%, dan untuk yang secara spesifik kegiatan pendidikan adalah 3,4\%. Persentase anggaran di atas $20 \%$ adalah anggaran setelah ditambah belanja pegawai. Dengan demikian, wacana tentang minimum anggaran 
pendidikan $20 \%$ mempunyai relevansi yang terbatas berkenaan dengan keberhasilan kebijakan pendidikan.

\section{DAFTAR PUSTAKA}

Abdul Manaf. 2018. "Manajemen Sarana dan Prasarana Pendidikan Pada Madrasah/Sekolah”,Dosen tetap STI tarbiyah al-hilal sigli. Diunduh pada tanggal 15 April.

Data hasil Observasi di Madrasah Ibtidaiyah Candirejo, Klaten, jawa Tengah yang dilakukan pada hari Jum'at tanggal 13 April 2018 pukul 08.20 Wit

Data hasil Observasi dan wawancara di Madrasah Ibtidaiyah Candirejo, Klaten, Jawa Tengah yang dilakukan pada hari Jum'at tanggal 20 April 2018 pukul 08.20 Wit.

Fuadi Aziz. 2014. Pengambilan Kebijakan Berbasis Education Management Information System (EMIS).Jurnal Pendidikan Islam, Volume III, Nomor 1, Juni.

H. M. Hasbullah. 2015. Kebijakan Pendidikan: Dalam Perspektif Teori, Aplikasi, dan Kondisi Objektif Pendidikan di Indonesia. Ed. 1 Cet 1,Jakarta: Raja Grafindo.

Helmawati. 2013. Pendidikan Nasional dan Optimalisasi Majelis Ta'lim: Peran aktif Majelis Ta'lim Meningkatkan Mutu Pendidikan.Jakarta: Rineka Cipta.

Imam dan Ara Hidayat. 2016. The Handbook Education Management Teori dan Praktik Pengelolaan Sekolah/Madrasah Di Indonesia.Jakarta: Prenadamedia Group.

Jamal Ma'mur Azmani. 2009. Manajemen Pengelolaan Dan Kepemimpinan Pendidikan Profesional. Yogyakarta: DIVA Press.

Martinus Tanggela. 2013. "Analisis Implementasi Kebijakan Pengelolaan Sarana dan Prasarana Sekolah Di SMP Negeri 2 Batu”. Jurnal Kebijakan dan Pengembangan Pendidikan Volume 1, Nomor 1 Januari.

Muhaimin, Suti'ah, Sugeng Listyo Prabowo.2011. Manajemen Pendidikan Aplikasinya dalam Penyusunan Rencana Pengembangan Sekolah/Madrasah.Jakarta: Kencana Prenada Media Group.

Mulyasa. 2011. Manajemen dan Kepemimpinan Kepala Sekolah.Jakarta: PT Bumi Aksara.

Munirah. 2015.Sistem Pendidikan Di Indonesia: Antara Keinginan Dan Realita. Jurnal. Auladuna, VOL. 2 NO: 233-245 238. 2 Desember.

Nurul Hariswati. 2015. Analisa Akuntabilitas dan Transparansi tentang Implementasi Kebijakan Pengelolaan BOS.Jurnal EkonomiBisnis Vol. 6 No.1.

Permendikbud No. 26 tahun 2017 tentang Petunjuk Teknis Bantuan Oprasional Sekolah. 
Ratna Dewi. 2016. Kebijakan Pendidikan Di Tinjau dari Segi Hukum Kebijakan Publik.Jurnal Ilmu Hukum, Volume 7, Nomor 2, Oktober.

Riduwan. 2015. Belajar Mudah Penelitian untuk Guru-Karyawan dan Peneliti Pemula.Bandung: Alfabeta.

Sugiyono. 2016. Metode Penelitian Pendidikan pendekatan kuantitatif, kualitatif, dan $R \& D$. Bandung: Alfabeta.

Sulaiman Saat. 2015. Faktor-faktor Determinan dalam Pendidikan (Studi Tentang Makna dan Kedudukannya dalam Pendidikan), Jurnal Al-Ta'dib Vol. 8 No. 2, Juli-Desember.

Syaiful Sagala. 2008. Administrasi Pendidikan Kontemporer. Bandung: Alfabeta. 
